\title{
The histopathological effects of chronic electrical stimulation of the cat cochlea
}

by

\author{
R. K. Shepherd, G. M. Clark, R. C. Black and J. F. Patrick (Melbourne, \\ Australia)
}

\section{Introduction}

The success of a cochlear implant depends on stimulating an adequate number of viable spiral ganglion cells. The effect of chronic electrical stimulation on ganglion cells is therefore an important consideration when assessing the effectiveness and safety of such a device.

The histopathological assessment of chronic unstimulated intracochlear electrodes is now well documented (Simmons, 1967; Clark, 1973; Clark et al, 1975; Schindler and Merzenich, 1974; Schindler, 1976; Schindler et al., 1977; Sutton et ah, 1980). These experimental studies have used a variety of electrode designs, materials and surgical techniques. However, all have shown that chronic implantation has little effect on the peripheral nerves and the spiral ganglion cells adjacent to an implant, provided the insertion procedure is free of trauma and infection.

Infection associated with electrode insertion is known to significantly reduce the spiral ganglion population throughout a large region of the cochlea. Clark (1977) showed an 80-90 per cent loss in the basal turn where localized infection occurred without associated surgical trauma.

It is also apparent that surgical damage to the cochlea during electrode insertion can result in a marked or total spiral ganglion loss which depends on the extent and location of the insult. Schindler and Merzenich (1974) estimated that a 70-80 per cent spiral ganglion cell loss followed the perforation of the basilar membrane by an electrode tip during electrode insertion. Regions remote from the damaged area were not affected. Sutton et al. (1980) also showed that a significant spiral ganglion cell loss occurred when trauma was restricted to the stria vascularis.

From these and other studies it is apparent that damage to the basilar membrane, osseous spiral lamina, stria vascularis or Reissner's membrane will result in a significant, localized reduction in the spiral ganglion population. More importantly, however, they have also demonstrated that large populations of spiral ganglion cells survive chronic implantation.

Following the development of suitable stimulation regimes for cortical electrodes (Pudenz et al., 1977; Brummer and McHardy, 1977) it has become apparent that short-duration, symmetric, biphasic, current waveforms provide the most electrochemically safe means of chronic stimulation of neural tissue. Although no 'safe' stimulation regime has been defined for intracochlear stimulation, all reported animal studies have used biphasic rather than monophasic pulses (Simmons, 1979; Walsh et al., 1980).

In the present study a low source- 
impedance, biphasic stimulator has been used as it ensures phase asymmetries of $0.05-0.005$ per cent for the stimuli used, and this results in minimal faradaic current products. The histopathological effects of chronic intracochlear electrical stimulation were evaluated for periods of up to 1,040 hours of continuous stimulation. Both histopathological and statistical assessments of the spiral ganglion cell populations of control and stimulated cochleas were made.

\section{Methods and Materials}

This study was carried out on ten cats. They were examined pre-operatively to make sure that their tympanic membranes were otoscopically normal. Anaesthesia was maintained with pentobarbitone sodium (40 mg./kg. i.v.), and the surgery was performed by an otolaryngologist using aseptic procedures. The bulla was exposed using a dorso-lateral approach and an opening in it enlarged until the round window was completely visible. The round window membrane was then incised with a fine needle and an electrode array inserted for a distance of $6 \mathrm{~mm}$. along the scala tympani.

The intracochlear array was prepared by welding three $0.3 \mathrm{~mm}$. wide platinum ring electrodes around a Silastic ${ }^{\circledR}$ tube (OD $0.64 \mathrm{~mm}$.), with a $1 \mathrm{~mm}$. separation between each electrode. It was also constructed with a Silastic ${ }^{\circledR}$ disc, and a Teflon $^{\circledR}$ felt collar (Fig. 1). The Silastic ${ }^{\circledR}$ disc was designed for placing in the scala tympani to provide a firm anchor, and the Teflon ${ }^{\circledR}$ collar for sealing the opening to minimize the entry of infection (Clark et al., 1980).

Both cochleas were implanted, one side being stimulated while the other served as a control. Following surgery each animal received an injection of Cloxacillin sodium (500 mg.) and Ampicillin sodium (500 mg), and had Ampicillin sodium administered orally each day for five days in a dose of $100 \mathrm{mg}$./day.

After a further five days, to allow

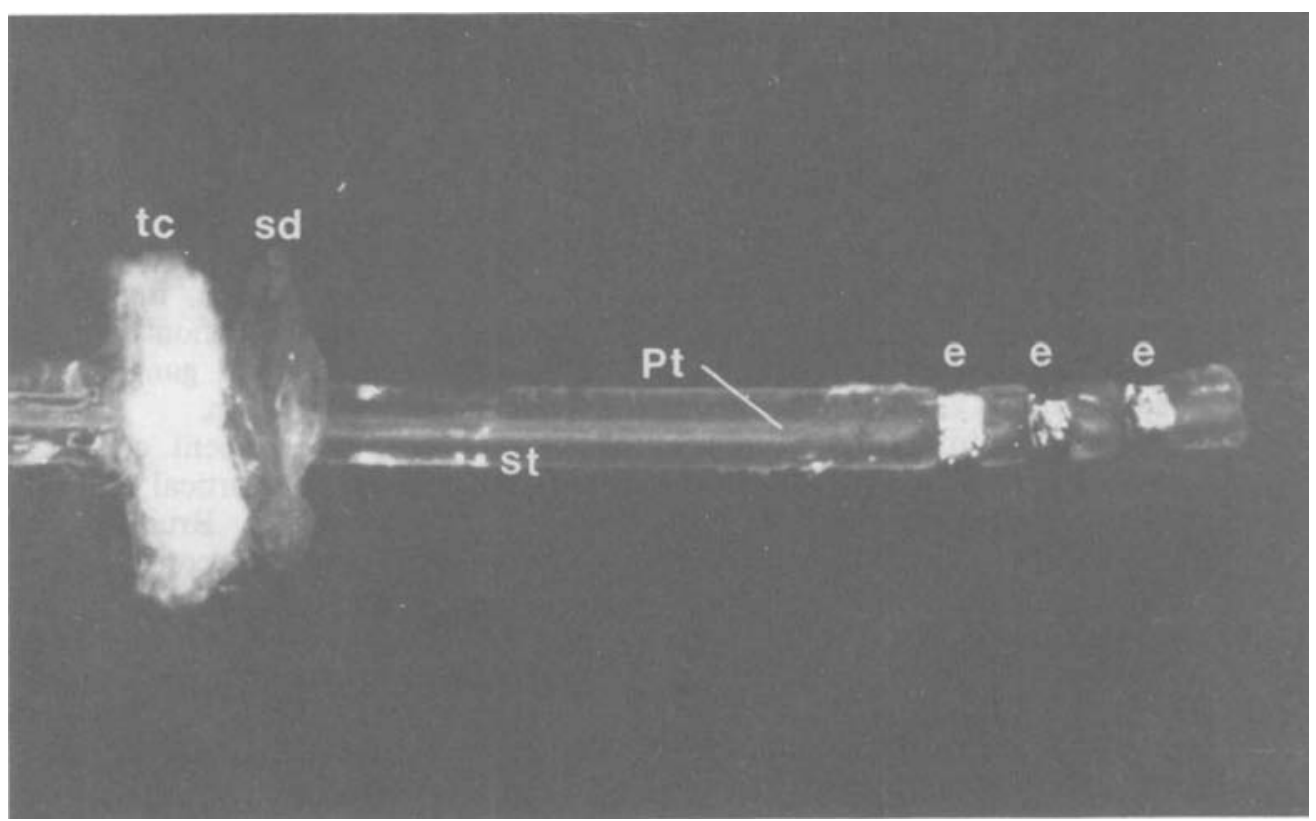

FIG. 1

Micrograph of intra-cochlear electrode array similar to that used in this study. e, platinum ring electrode; sd, Silastic $^{\circledR}$ disc; Pt, Teflon ${ }^{\circledR}$ insulated 0.025 mm. OD platinum wires; tc, Teflon ${ }^{\circledR}$ collar. $\times 25$. 
for complete recovery, each animal was placed on an electrical stimulation program where a low source-impedance biphasic stimulator was used to stimulate auditory nerve fibres at 200 pulses/second (pps.) and $0.2 \mathrm{msec}$. $/$ phase.

A supra-threshold stimulus current level midway between threshold and one which gave an aversive response was used. This was determined by observation and Auditory Brainstem Response (ABR) data, and was in the range $0.4 \mathrm{~mA}$. to $1.5 \mathrm{~mA}$. The cats were stimulated continuously for periods ranging from 91 hours to 1,040 hours.

On completion of the chronic electrical stimulation program, each animal was sacrificed and perfused intra-arterially with heparinized normal saline followed by buffered 10 per cent formalin. Following the removal of the electrode each temporal bone was trimmed, post-fixed in Heidenhain Susa solution, decalcified in neutral EDTA solution, and embedded in Spurr's epoxy resin. Owing to difficulties with the embedding techniques only the temporal bones of cat 15 (control), cat 53 (stimulated and control), and cat 56 (stimulated) could be sectioned. This was carried out in a coronal and mid-modiolar plane at a thickness of $3 \mu \mathrm{m}$. using a Reichart-Jung Autocut. Sections were collected every $120 \mu \mathrm{m}$. and stained with haematoxylin and eosin to produce a tracer series.

Using this series, spiral ganglion cell densities were determined for both the lower and upper regions of the basal turn and the lower region of the middle turn of each cochlea (regions $A, B$ and $C$ respectively). It should be noted that the intracochlear electrode was located in the scala tympani close to region A. Only spiral ganglion cells with visible nuclei were counted, and as the total populations were not required, no correction factor for section thickness was applied.

The mean spiral ganglion cell density was determined for each region, and these values were examined for statistically significant variations by applying a two-way analysis of variance.

\section{Results}

\section{Histopathological observations}

Cat 56

This animal was stimulated continuously for 1,008 hours at a mid-current range of $0.5 \mathrm{~mA}$. The stimulation regime was terminated for 23 days and recommenced for a further 32 hours. The animal was sacrificed three days later -84 days after the implant operation. Electrically evoked ABR data were recorded every 250 hours of stimulation, and the ABR thresholds showed no significant variation during the stimulation program.

Histological examination of the stimulated cochlea revealed fibrous tissue encapsulation of the electrode and new bone growth along the osseous spiral lamina, basilar membrane and spiral ligament in regions adjacent to the electrode (Fig. 2). There was no apparent damage to the basilar membrane or stria vascularis due to the presence of the electrode; however, there was an absence of hair cells throughout the cochlea. There was also evidence of damage to the osseous spiral lamina $1 \mathrm{~mm}$. from the round window, resulting in a significant loss of spiral ganglion cells. It should be noted that this region of the spiral ganglion was not included in the statistical analysis of the lower basal spiral ganglion region. At $2 \mathrm{~mm}$. from the round window, however, there was minimal osseous spiral lamina damage, and the adjacent spiral ganglion cell population showed no significant loss and appeared normal (Fig. 3).

\section{Cat 53}

This animal was stimulated continuously for 245 hours at a mid-current range of $0.5 \mathrm{~mA}$. The animal was sacrificed 16 days after the completion of its stimulation program-78 days after the implant operation. Both stimulated and control cochleas are reported.

Histological examination of the stimulated cochlea revealed fibrous tissue encapsulation of the electrode without associated new bone growth. Some poly- 


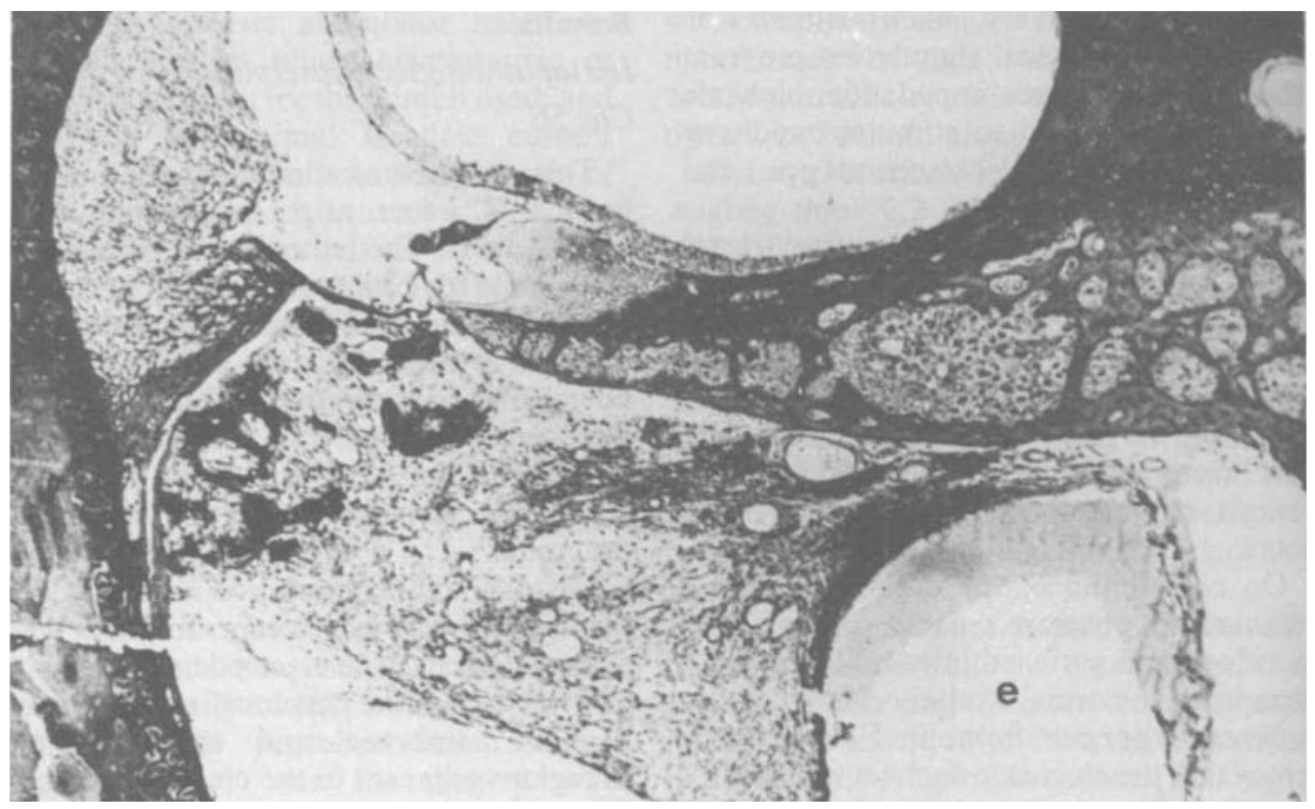

FIG. 2

Photomicrograph of the left cochlea in Cat 56 . This cochlea was electrically stimulated for 1,040 hours. e, electrode tract. $\times 50$.

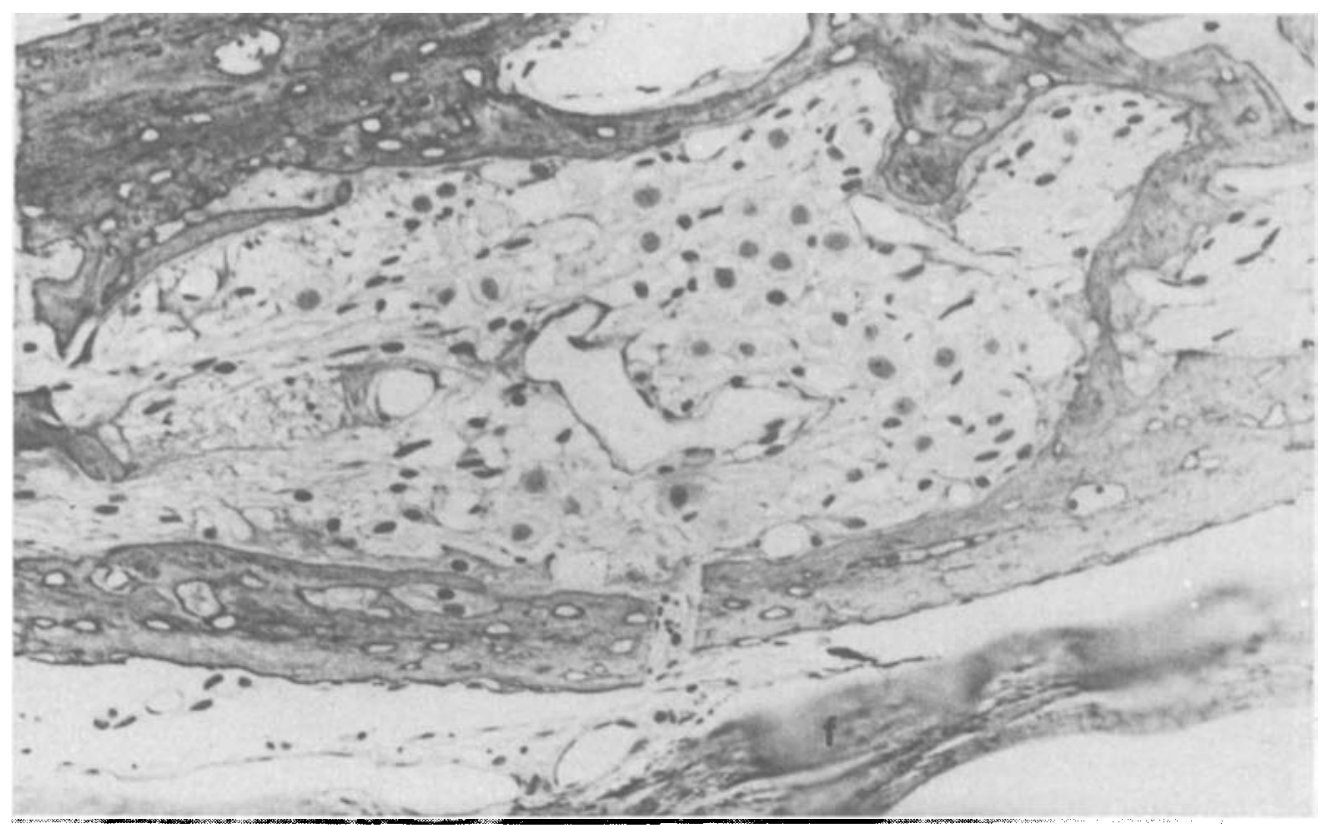

Fic. 3

Photomicrograph of the spiral ganglion cell population in the basal turn of the cat cochlea $56 \mathrm{~L} 2 \mathrm{~mm}$. from the round window. Note the fractured osseous spiral lamina. $\mathrm{f}$, fibrous tissue encapsulation. $\times 80$. 


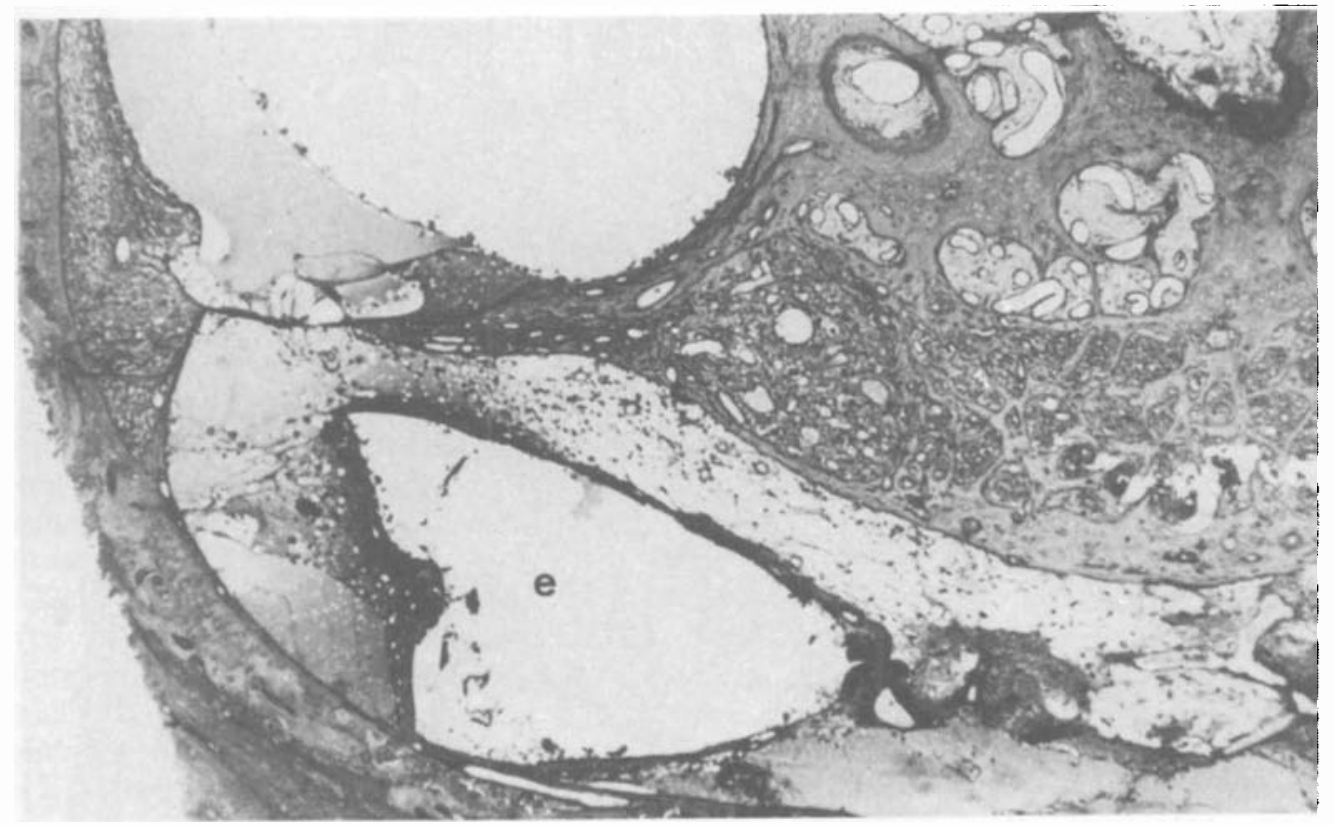

FIG. 4

Photomicrograph of the basal turn of cat cochlea 53L. This cochlea was electrically stimulated for 245 hours. $\mathrm{e}$, electrode tract. $\times 50$.

morphonuclear leucocytes were observed in a small region of the basal turn; in addition, an eosinophilic exudate was obvious throughout all scalae (Fig. 4).

The basilar membrane, organ of Corti and stria vascularis were present in all turns, although there was no evidence of hair cells. Spiral ganglion cells, both adjacent to the electrode and in all other turns, appeared healthy and in apparently normal populations (Fig. 5).

Histological examination of the control cochlea revealed a fine fibrous tissue encapsulation of the electrode without associated new bone growth. Some polymorphonuclear leucocytes were observed in a small region of the scala tympani in the basal turn; in addition, an eosinophilic exudate was obvious throughout the scala vestibuli.

The basilar membrane and stria vascularis were present in all turns although the organ of Corti was absent for a distance of 0.5-2.2 $\mathrm{mm}$. from the round window. Further basal-and apical-wards from this region, the structure of the organ of Corti appeared normal, with hair cells generally apparent in both middle and apical turns.

The spiral ganglion cell population appeared normal throughout the cochlea, except for the region where there was loss of the organ of Corti. In this case there was an estimated 10 per cent reduction in the spiral ganglion cell population.

\section{Cat 15}

This animal was sacrificed 87 days after the implant operation. The right cochlea was not stimulated during this period, and thus serves as a control.

Histological examination revealed loose fibrous tissue associated with the electrode, together with new bone growth apparently originating from the osseous spiral lamina and spiral ligament (Fig. 6).

There was no indication of electrodeinduced trauma, the basilar membrane, stria vascularis and supporting cells of the organ of Corti were present in all turns, and sensory 


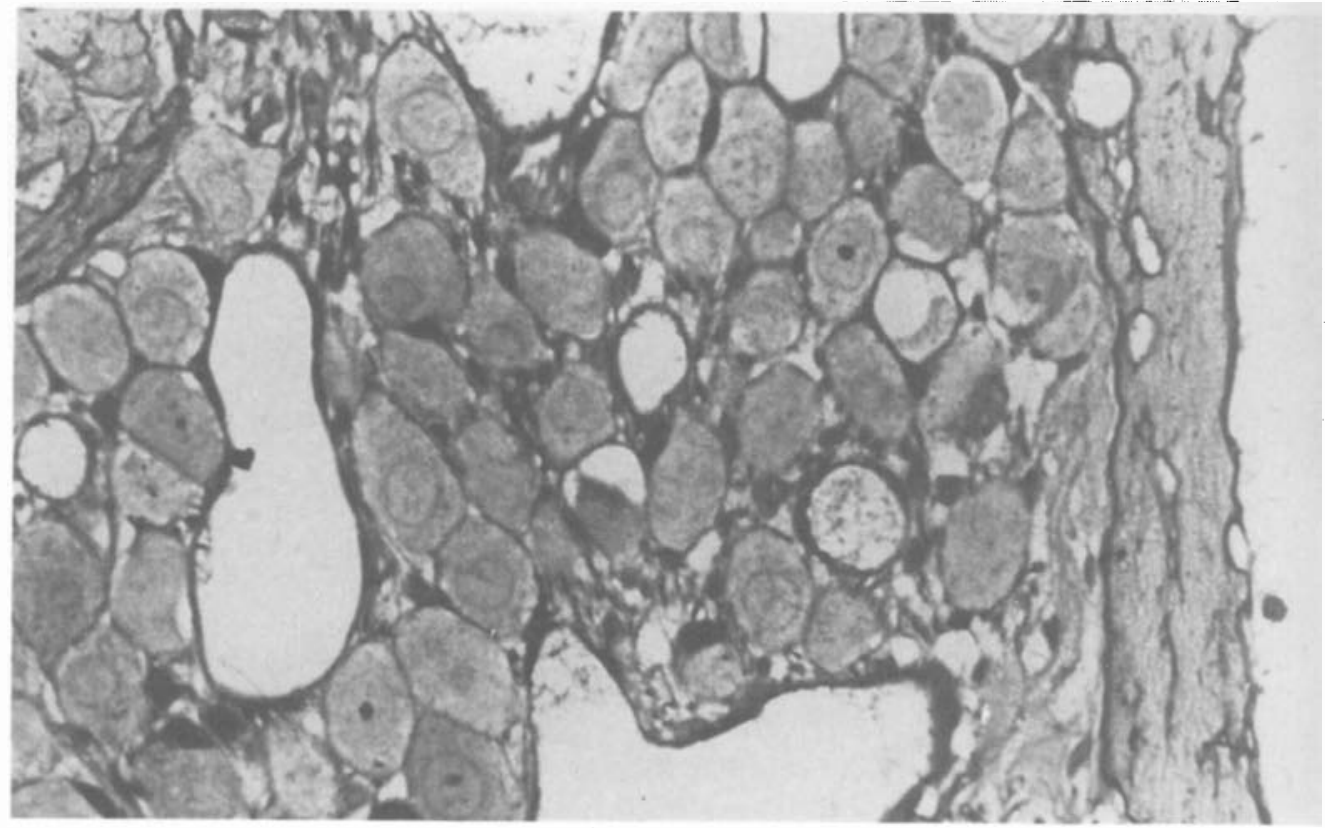

Fig. 5

Photomicrograph of spiral ganglion cells adjacent to the electrode in the basal turn of cat cochlea 53L. $\times 260$.

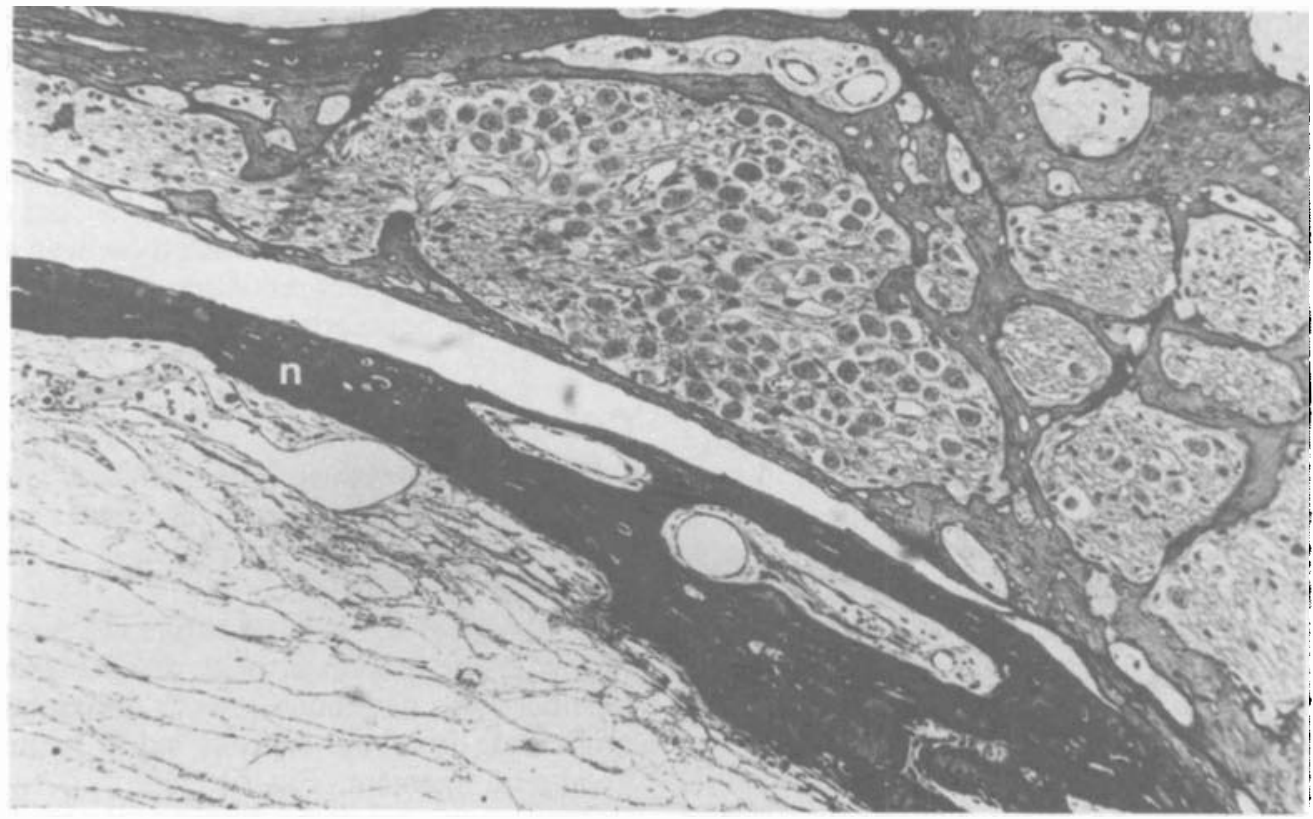

Fig. 6

Photomicrograph of new bone formation and spiral ganglion cell region adjacent to the control electrode in cat cochlea 15 . n, new bone. $\times 70$. 
hair cells were evident in the middle and apical turns. The spiral ganglion cells appeared normal throughout the cochlea.

\section{Statistical Analysis of Spiral Ganglion Cell Densities}

The mean spiral ganglion cell densities for regions $A, B$ and $C$ of each cochlea are given in Table I.

A two-way analysis of variance was performed on these data to compare the spiral ganglion cell density among the four cochleas, the three regions, and interactions between them.

The results of the analysis of variance are given in Table II. There was no significant difference between regions at the 5 per cent probability level; however there was a significant difference between cochleas at the 1 per cent probability level. In addition, there was a significant difference between cochleas $53 \mathrm{~L}$ and $53 \mathrm{R}$ at the 1 per cent probability level. The interaction between cochleas and regions was significant at the 5 per cent probability level. The low average for $56 \mathrm{~L}$ region $\mathrm{C}$ appears atypical.

\section{Discussion}

The results from this study indicate that chronic intracochlear electrical stimulation in cats does not result in a significant loss of the spiral ganglion cell population in the region of the electrode, for a charge-balanced biphasic pulsing stimulation regime. In addition, the amount and site of new bone growth appears to be independent of electrical stimulation.

The histopathological examination of each cochlea revealed no apparent decrease in the viable spiral ganglion cell population of cochleas treated with electrical stimulation, when compared with implanted, non-

TABLE I

MEAN SPIRAL GANGLION CELL DENSITIEs ${ }^{a}$

\begin{tabular}{|c|c|c|c|c|c|c|}
\hline \multirow{2}{*}{ Cochlea } & \multirow{2}{*}{$\begin{array}{c}\text { Stimulated/ } \\
\text { Control }\end{array}$} & \multicolumn{3}{|c|}{ Spiral ganglion region } & \multirow{2}{*}{ Total } & \multirow{2}{*}{ Mean } \\
\hline & & A & B & $\mathrm{C}$ & & \\
\hline $\begin{array}{l}15 R \\
53 R \\
53 L \\
56 L\end{array}$ & $\begin{array}{c}\text { Control } \\
\text { Control } \\
\text { Stimulated } \\
\text { Stimulated }\end{array}$ & $\begin{array}{l}1,298 \\
1,390 \\
1,491 \\
1,137\end{array}$ & $\begin{array}{l}1,289 \\
1,000 \\
1,370 \\
1,186\end{array}$ & $\begin{array}{r}1,309 \\
1,369 \\
1,676 \\
792\end{array}$ & $\begin{array}{l}3,896 \\
3,759 \\
4,537 \\
3,115\end{array}$ & $\begin{array}{l}1,299 \\
1,253 \\
1,512 \\
1,038\end{array}$ \\
\hline $\begin{array}{l}\text { Total } \\
\text { Mean }\end{array}$ & & $\begin{array}{l}5,316 \\
1,329\end{array}$ & $\begin{array}{l}4,845 \\
1,211\end{array}$ & $\begin{array}{l}5,146 \\
1,286\end{array}$ & 15,307 & $1,275.6$ \\
\hline
\end{tabular}

a Notes: (i) Spiral ganglion cell densities are given in cells $/ \mathrm{mm}^{2}$.

(ii) Spiral ganglion region $\mathbf{A}$ was adjacent to the intracochlear electrode.

TABLE H

ANALYSIS OF VARIANCE ON SPIRAL GANGLION CELL DENSITY DATA ${ }^{a}$

\begin{tabular}{lcccc}
\hline Source of variation & df. & Sum of squares & Mean squares & F \\
\hline Cochleas & 3 & 340,143 & 113,400 & $8.42^{*}$ \\
Region & 2 & 28,445 & 14,220 & 1.06 \\
Interaction & 6 & 207,711 & 34,620 & $2.57^{* *}$ \\
Total & 11 & 576,299 & 13,460 & \\
Estimated error variance based on variation within regions & & \\
\hline
\end{tabular}

a Notes: $*=$ Significant effects at the 1 per cent level. $* *=$ Significant effects at the 5 per cent level. 
stimulated control cochleas. Spiral ganglion cell density measurements (Table I) support this observation. There was, however, a dramatic reduction in the viable spiral ganglion cell population close to a region of osseous spiral lamina damage due to the electrode insertion (56L). This loss of viable spiral ganglion cells was observed to be very localized.

These preliminary results support the findings of other investigators addressing this question. Simmons (1979) found negligible neural degeneration following short periods of direct auditory nerve stimulation totalling 40 hours for periods up to 16 months. Similarly Walsh et al. (1980) reported little pathological effect on the neural periphery following continuous stimulation for periods of up to 800 hours at current levels ranging from 2-8 mA., although some local neural degeneration adjacent to electrodes was reported.

A statistical examination of the mean spiral ganglion cell densities of both control and stimulated cochleas did reveal a significant variation among cochleas. Examination of those data indicates that this variation was not due to electrical stimulation. For example, cochlea $53 \mathrm{~L}$, which was stimulated for 245 hours, had the largest mean cell density among the four cochleas examined. The authors feel that a statistical analysis of spiral ganglion cell densities among control and stimulated cochleas is an effective and objective means of analysing these data, provided that the histological techniques are uniform for each cochlea.

Hair cell loss was recorded throughout the chronically stimulated cochleas; however, both control cochleas showed inner and outer hair cell survival in middle and apical turns. Although firm conclusions cannot be drawn from the limited data available, further studies will evaluate the effect of chronic stimulation on hair cell survival.
Calcification was observed in both stimulated and control cochleas, thus indicating that it is probably not a function of electrical stimulation. The new bone was not directly adjacent to the electrode but appeared to originate from the endosteal lining of the scala tympani, in particular the osseous spiral lamina and the spiral ligament. Calcification does not appear to be a function of electrode design, as the formation of new bone has been reported by a number of investigators using a variety of designs (e.g. Clark, 1977; Walsh et al, 1980). Indeed, extensive new bone growth was reported following the histological examination of one of the first two implanted human cochleas to become available (Johnsson et al, 1979). It is worth noting, however, that no serious qualitative assess ment of various implant materials on the formation of new bone has been carried out and our observations suggest that new bone is always accompanied by a fibrous tissue reaction.

Although the results of this and other studies are encouraging, there is a need to carry out further chronic stimulation studies for a more complete evaluation of intracochlear electrical stimulation.

\section{Acknowledgements}

We would like to acknowledge financial assistance from the Department of Science and Technology (formerly the Department of Productivity) of the Australian Government and the National Health and Medical Research Council. We would also like to thank Professor E. Williams for statistical advice and our colleagues Dr. R. Webb, Dr. B. Pyman, Mr. G. Ewing, Mr. D. Bloom, Mr. D. Clark, Mrs. S. Derham and Mr. F. Rickards for their help, and Mrs. E. Utton for the typing.

\section{References}

Brummer, S. B., and McHardy, J. (1977) Current problems in electrode development: In Functional Electrical Stimulation Applications in Neural Prostheses, Vol. 3, ed. F. T. Hambrecht and J. B. Reswick. Marcel Dekker Inc., New York 
Clark, G. M. (1973) A hearing prosthesis for severe perceptive deafness-experimental studies. Journal of Laryngology and Otology, 87: 92-97.

Clark, G. M. (1977) An evaluation of per-scalar cochlear electrode implantation techniques-an histopathological study in cats. Journal of Laryngology and Otology, 91: 185.

Clark, G. M., Kranz, H. G., Minas, H., and Nathar, J. M. (1975) Histopathological findings in cochlear implants in cats. Journal of Laryngology and Otology, 89: 495.

Clark, G. M., Pyman, B. C., and Pavillard, R. E. (1980) A protocol for the prevention of infection in cochlear implant surgery. Journal of Laryngology and Otology, 94: 1377.

Ghorayer, B., Sarwat, A., and Linthicum, F. H. (1980) Viable spiral ganglion cells in congenital and acquired profound hearing loss. Journal of Laryngology and Otology, 94: 367.

Johnsson, L. G., House, W. F., and LinthicuM, F. H. (1979) Bilateral cochlear implants: Histological findings in a pair of temporal bones. Laryngoscope, 89: 759.

Pudenz, R. H., Agnew, W., Yuen, T. G. H., and Bullara, L. A. (1977) Electrical stimulation of the brain: Light and electron microscopy studies: In Functional Electrical Stimulation Applications in Neural Prostheses, Vol 3, ed. F. T. Hambrecht and J. B. Reswick. Marcel Dekker Inc., New York.

Schindler, R. A. (1976) The cochlear histopathology of chronic intracochlear implantation. Journal of Laryngology and Otology, 90: 445.

Schindler, R. A., and Merzenich, M. M. (1974) Chronic intracochlear electrode implantation: cochlear pathology and acoustic nerve survival. Annals of Otology, Rhinology and Laryngology, 83: 202.

Schindler, R. A., Merzenich, M. M., WhITE, M. W., and BjorkRoTh, B. (1977) Multielectrode intracochlear implants. Nerve survival and stimulation patterns. Archives of Otolaryngology, 103: 691.

Simmons, F. B. (1967) Permanent intracochlear electrodes in cats, tissue tolerance and cochlear microphonics. Laryngoscope, 77: 171.

Simmons, F. B. (1979) Electrical stimulation of the auditory nerve in cats. Long term electrophysiology and histological results. Annals of Otology, Rhinology and Laryngology, 88: 533.

Sutton, D., Miller, J. M., and Pfingst, B. G. (1980) Comparison of cochlear histopathology following two implant designs for use in scala tympani. Annals of Otology, Rhinology and Laryngology, 89: Supplement 66, 11.

Walsh, S. M., Merzenich, M. M., Schindler, R. A., and Leake-Jones, P. A. (1980) Some practical considerations in development of multichannel scala tympani prostheses. Audiology, 19: 164.

Address for correspondence:

Professor G. M. Clark,

Department of Otolaryngology,

University of Melbourne,

The Royal Victorian Eye and Ear Hospital,

East Melbourne 3002,

Australia. 



\section{University Library}

\section{- M M N E R VA A gateway to Melbourne's research publications}

Minerva Access is the Institutional Repository of The University of Melbourne

Author/s:

Shepherd, R. K.;Clark, Graeme M.;Black, R. C.;Patrick, J. F.

Title:

The histopathological effects of chronic electrical stimulation of the cat cochlea

Date:

1983

Citation:

Shepherd, R. K., Clark, G. M., Black, R. C., \& Patrick, J. F. (1983). The histopathological effects of chronic electrical stimulation of the cat cochlea. The Journal of Laryngology and Otology, April, 97, 333-341.

Persistent Link:

http://hdl.handle.net/11343/27189 